\title{
I mproving quality of rice straw through treatment with urea and midden soil for large animals
}

\author{
M Akter ${ }^{1}$, MJ Khan' ${ }^{2}$, MA Akbar ${ }^{2}$, M Asaduzzaman ${ }^{3}$
}

\begin{abstract}
${ }^{1}$ Department of Animal Nutrition, Genetics and Breeding, Sher-e-Bangla Agricultural University, Dhaka 1207;
${ }^{2}$ Department of Animal Nutrition, Bangladesh Agricultural University, Mymensingh 2202; ${ }^{3}$ Department of Dairy Science, Sher-e-Bangla Agricultural University, Dhaka 1207, Bangladesh
\end{abstract}

\begin{abstract}
Twelve indigenous growing cattle (live weight $130.00 \pm 1.67 \mathrm{~kg}$ ) were selected and divided into four groups having three animals in each group. Group A, B, C and D supplied $3.0 \%$ urea $+2.0 \%$ midden soil, $3.0 \%$ urea $+3.0 \%$ midden soil, $3.0 \%$ urea $+4.0 \%$ midden soil and $3.0 \%$ urea $+5.0 \%$ midden soil treated rice straw. In addition to this all the animals were supplied $2 \mathrm{Kg}$ green grass, $450 \mathrm{~g}$ concentrate mixture and $40 \mathrm{~g}$ salt per $100 \mathrm{~kg}$ body weight. Rice straw treated with $3.0 \%$ urea $+2.0 \%$ midden soil resulted an improvement in crude protein content of rice straw from 3.30 to $7.08 \%$ which was further increased by $7.40,7.90$ and $8.14 \%$ treatment with $3.0 \%$ urea $+3.0 \%$ midden soil, $3.0 \%$ urea $+4.0 \%$ midden soil and $3.0 \%$ urea $+5.0 \%$ midden soil respectively. The addition of $5.0 \%$ midden soil as a urease source with $3.0 \%$ urea (D) treated rice straw not only significantly $(P<0.01)$ increased the coefficient of digestibility of DM, CP, CF, EE and NFE but also significantly $(P<0.05)$ increased the coefficient of digestibility of OM than other treatments. Digestible organic matter (DOM), crude protein (DCP), digestible crude fibre (DCF), digestible nitrogen free extract (DNFE) and total digestible nutrients (TDN) contents were significantly $(p<0.01)$ higher in diet D in comparison to diet A, B and C.
\end{abstract}

Key words: Digestibility, midden soil, rice straw, urea

Bangladesh Animal Husbandry Association. All rights reserved.

Bang. J. Anim. Sci. 2013. 42 (1): 29-34

\section{I ntroduction}

Rice straw alone contributes $87 \%$ of the roughage feed of animals and also the major feed for ruminants in Bangladesh. But rice straw is very low in fermentable carbohydrate, along with low protein, unbalanced mineral and vitamin content and high in cellulose, hemicellulose, lignin and silica content resulting in low voluntary intake and low digestibility of nutrients thus limiting the ruminal microbial functions. In straw, cellulose is associated with lignin and form a complex physico- chemical lignocellulose bond which is more or less unavailable to the microbes in the rumen. Extensive research has been carried out for several decades on improving nutritive value of cereal straws for livestock using physical, chemical and biological treatments and varying degree of success has been reported from technical aspects, however, economic benefit and social acceptance of these technologies have been limited (Rangnekar 2005). Urea has advantages over anhydrous ammonia in Bangladesh mainly because it can be locally manufactured, is readily available to farmers, less expensive, easier to handle and is the most practical method for use in South East Asian countries (Saadullah et al. 1981; Jayasuriya and perera 1982). Straw treated with urea solution (as a source of ammonia) is ensiled for 3-4 weeks before being eaten by animals. Farmers in such a situation often prefer to use untreated straw rather than to treat it for long time. In early reports of such treatments (Kiangi et al. 1981), it was suggested that an exogenous source of urease was necessary in order to hydrolyse the urea to produce a more rapid improvement in the nutritive value of straw. Munoze et al. (1991) reported that addition of urease has been reported to hasten the process of conversion of urea to ammonia. Treatment time could be successfully reduced from 2-3 weeks to 5 days by incorporating a source of urease enzyme at the time of urea solution application (Jayasuriya and Pearce 1983). Midden soil is a good source of urease enzyme which is found in lower part of the cowdung pit, useable to the farmers free of cost in the field level. Therefore incorporation of midden soil at the time of urea treatment of rice straw may be an easy adaptable technique for reducing treatment time as well as improving quality of straw.

\section{Materials and Methods}

Rice straw was purchased from a local farmer for 
the experimental purpose. Rice polish, mustard oil cake, dicalcium phosphate and salt were purchased from a local market. Green grasses were cultivated in the fodder plot. Rice straw was chopped at a particle size of 4 to $6 \mathrm{~cm}$ prior to treatment. Midden soil was collected from different sides of the cowdung pit, mixed properly, dried in the sun and composite sample was ground by an automatic grinder and preserved. Mustard oil cake was also ground with the help of mechanical grinder. Commercial fertilizer grade granulated urea $\left(\mathrm{NH}_{2}-\mathrm{CO}-\mathrm{NH}_{2}\right.$, $43 \% \mathrm{~N}$ ) was purchased prior to treatment.

Ten (10) kg of rice straw was spreaded on a clean concrete floor and commercial urea at the rate of $3.0 \%$ (on straw DM basis) was dissolved in 10 litres of water. The urea solution was sprayed throughout the chopped straw with a hand garden sprayer and the straw was mixed properly to achieve uniform wetting by the hand. Then $2.0 \%$ finely ground midden soil was hand sprayed to straw according to treatments and mixed manually as evenly as possible. In this way, total quantity of straw was mixed with urea solution and midden soil. Treated straws were kept into a silo pit, squeezed sufficiently to expel excess air and covered by double layer polythene sheet to ensure anaerobic condition. This preserved straw was kept for 7 days before feeding to the animals of group A. For groups B, C and D, finely ground $3.0 \%, 4.0 \%$ and $5.0 \%$ midden soil were thoroughly added with urea treated straw at the time of treatment and preserved for 7 days before feeding animals.

Twelve indigenous growing cattle with an average body weight of $130.00 \pm 1.67 \mathrm{Kg}$ were selected for this study following Randomized Block Design (RBD). The animals of group A received $3.0 \%$ urea $+2.0 \%$ midden soil treated ensiled straw, group B received $3.0 \%$ urea $+3.0 \%$ midden soil treated ensiled straw, group C received $3.0 \%$ urea $+4.0 \%$ midden soil treated ensiled straw and group $D$ received $3.0 \%$ urea $+5.0 \%$ midden soil treated ensiled straw. Animals were supplied with treated rice straw adlibitum, $2 \mathrm{Kg}$ green grass and $450 \mathrm{~g}$ concentrate mixture per $100 \mathrm{Kg}$ live weight of animal where rice polish and mustard oil cake were mixed in 1:1 ratio, dicalcium phosphate was given @ 10g/100 kg body weight. Salt was supplied to the animal @ $40 \mathrm{~g} / 100 \mathrm{~kg}$ body weight per day. The ration was adjusted weekly with the increase of body weight of the animals.
At first treated straw was taken out from silo and kept for half an hour in the air before feeding to remove the pungent smell of treated straw. In the mean time concentrate mixture was supplied to the animal. Green grass was chaffed and mixed with the straw. Straw and green grass of individual animal was divided into two halves and supplied to the animals twice daily, at $8.00 \mathrm{a} . \mathrm{m}$. in the morning and at 4.00 p.m. in the afternoon. Water was supplied to the animal adlibitum basis.

Experimental diet was supplied to all the animals twice daily and left over was weighed in the following morning before offering feed. Feed intake was recorded by deducting the leftover from the feed supplied. The values were expressed as fresh and dry matter basis. During the experimental period, the animals consumed all the green grasses and concentrate but refused a small quantity of straw every day.

Treated straw, green grass and concentrate mixture were collected for chemical analysis. After collection treated straw and green grass were sun dried and mixed properly. Then these were grind and kept into a plastic container and labeled on it.

Faeces were collected manually from each animal throughout the day and night immediately after defecation, during the collection period and then kept in polythene bags to avoid the losses of volatile nitrogen and contamination with dirt and urine. Following morning total quantity of faeces voided was weighed and recorded against each animal. About $10 \%$ of the everyday well mixed faeces of each animal were collected, sun dried and stored in polythene bags. At the end of the collection period the sun dried faeces were composites together and then ground in $1 \mathrm{~mm}$ sieve which was used for proximate components analysis except two components DM and CP which were determined from fresh faeces. The daily feed intake and left over were also recorded during that period. Keen observation was taken with the unwanted mixing of urine and feces in that time.

Chemical analysis for crude protein (CP), crude fiber (CF), ether extract (EE), Ash and nitrogen free extract (NFE) were done with respective samples of feed, left over and faces following the methods of AOAC (2004). All the samples were analyzed in duplicate and mean values were recorded.

For every parameter, the data were analyzed using the "MSTAT" statistical programme to 
compute analysis of variation (ANOVA) for a Randomized Block Design (RBD) and the mean values with standard error deviation (SED) were recorded. Duncan's Multiple Range Test (DMRT) was also done for different parameter to compare the treatment means.

\section{Results and Discussion}

\section{Chemical composition of feed ingredients}

The chemical composition of rice straw, 3.0\% urea $+2.0 \%$ midden soil treated rice straw (ensiled), $3.0 \%$ urea $+3.0 \%$ midden soil treated rice straw (ensiled), 3.0\% urea $+4.0 \%$ midden soil treated straw (ensiled), 3.0\% urea $+5.0 \%$ midden soil treated straw (ensiled) and other feed ingredients is presented in Table 1 . It is seen from the table that rice straw contained $3.30 \%$ crude protein which was increased to $7.08 \%$ by treatment with $3.0 \%$ urea $+2.0 \%$ midden soil (ensiled) and also increased to $7.40 \%$ crude protein when treated rice straw with $3.0 \%$ urea+ $3.0 \%$ midden soil (ensiled). The value was increased further by addition of $4.0 \%$ midden soil at the time of $3.0 \%$ urea addition which is $7.90 \%$ and $8.14 \%$ with the addition of $5.0 \%$ midden soil. Similar observation was also made by Khan et al. (1999) who stated that addition of urease sources increased the rate of urea hydrolysis and crude protein content of treated straw. Malek et al. (2008) reported that CP concentration of straw treated with soybean seed meal showed highest value followed by cowpea seed meal, midden soil and only urea against $4.20 \%$ in untreated straw and the difference among treatments were highly significant $(p<0.01)$. Untreated rice straw contains $36.10 \%$ CF which was decreased by treatment with $3.0 \%$ urea with $2.0 \%$ midden soil (34.90\%). The value has been further decreased by addition of urease source at the time of treatment which were $33.80 \%$ with addition of $3.0 \%$ midden soil (B), $33.60 \%$ with addition of $4.0 \%$ midden soil (C) and $32.80 \%$ with addition of $5.0 \%$ midden soil (D). This result indicated that the inclusion of increased level of midden soil with urea treated rice straw reduced the CF content. According to Goto (1995), addition of urease at the time of urea (ammonia) treatment act on roughages by cleaving ester linkages between cell wall polymers. By using 2.0, 3.0, 4.0 and $5.0 \%$ midden soil as a source of urease enzyme with urea treated rice straw helped to reduce the CF\% in experimental diet $A, B, C$ and $D$ by increasing cell wall porosity, which makes polysaccharides more available to enzymatic hydrolysis. Hossain (2010) reported a lower CF content of straw when straw was treated with $3.50 \%$ urea, $3.50 \%$ urea+ $2.50 \%$ midden soil and $2.50 \%$ chick pea. The ether extract (EE) content was high in $3.0 \%$ urea $+4.0 \%$ midden soil $(2.10 \%)$ and $3.0 \%$ urea + $5.0 \%$ midden soil $(2.20 \%)$ treated straw against $1.25 \%$ of the untreated rice straw because additives used in urea treated rice straw contains high EE. Ahmed (2003) who reported that EE contents was increased by addition of 4.0 and 6.0 $\%$ soybean meal with urea. Untreated rice straw contained $44.33 \%$ NFE where in group A $(2.0 \%$ midden soil), group B (3.0\% midden soil), group C (4.0\% midden soil) and group D (5.0\% midden soil) with $3.0 \%$ urea observed in lower NFE content (40.94, 41.66, 41.28 and $41.71 \%)$. Malek et al. (2008) and Hossain (2010) reported that the value for NFE of urease enzyme treated group was lower than untreated rice straw group. Rice straw contained $15.02 \%$ ash which increased to $15.06 \%, 15.09 \%, 15.12 \%$ and $15.15 \%$ by the treatment with $3.0 \%$ urea $+2.0 \%$ midden soil, $3.0 \%$ urea $+3.0 \%$ midden soil , 3.0\% urea $+4.0 \%$ midden soil and $3.0 \%$ urea $+5.0 \%$ midden soil respectively.

\section{Apparent digestibility of nutrient}

The apparent digestibility of different nutrients is shown in Table 2. The DM digestibility of the animals fed $3.0 \%$ urea $+5.0 \%$ midden soil treated straw $(68.73 \%)$ was significantly higher $(P<0.01)$ compared with that of animals fed $3.0 \%$ urea $+4.0 \%$ midden soil treated straw (66.46\%), $3.0 \%$ urea $+3.0 \%$ midden soil treated straw $(65.16 \%)$ and $3.0 \%$ urea $+2.0 \%$ midden soil treated straw $(62.47 \%)$. Bae et al. (1988) also found higher DM digestibility in cattle fed rice straw supplemented with soya-urease than untreated control group. This findings corresponds well with the results of Kamruzzaman (2005) who observed that inclusion of soybean meal as a urease source with urea treated straw significantly increased the coefficient of digestibility of DM.

The organic matter digestibility of group $C$ and $D$ was significantly higher $(p<0.05)$ than that of Group A and B. This may be due to that urease enzyme in midden soil were able to accelerate to release of ammonia from urea to extent that increased availability of organic matter. Wanapat et al. (1984) observed that the OM digestibility of barley straw increased from $52.0 \%$ to $59.0 \%$, when small amount of soybean was added at treatment time as a source of urease enzyme. 
Akter et al. (2013) Bang. J. Anim. Sci. 42 (1): 29- 34

Table 1. Chemical composition of diets and feed ingredients

\begin{tabular}{lccccccc}
\hline \multirow{2}{*}{ Feed Ingredients } & DM & \multicolumn{5}{c}{ Composition (g/100 gDM) } \\
\cline { 3 - 7 } & $\mathrm{g} / 100 \mathrm{~g}$ & $\mathrm{OM}$ & $\mathrm{CP}$ & $\mathrm{CF}$ & $\mathrm{EE}$ & $\mathrm{NFE}$ & Ash \\
\hline Rice straw & 88.70 & 84.98 & 3.30 & 36.10 & 1.25 & 44.33 & 15.02 \\
Diet A & 47.93 & 84.94 & 7.08 & 34.90 & 2.02 & 40.94 & 15.06 \\
Diet B & 48.27 & 84.91 & 7.40 & 33.80 & 2.05 & 41.66 & 15.09 \\
Diet C & 48.28 & 84.88 & 7.90 & 33.60 & 2.10 & 41.28 & 15.12 \\
Diet D & 48.45 & 84.85 & 8.14 & 32.80 & 2.20 & 41.71 & 15.15 \\
Green grass & 20.75 & 88.26 & 9.28 & 30.40 & 2.20 & 46.38 & 11.74 \\
Concentrate mixture & 91.73 & 87.29 & 17.15 & 9.16 & 11.89 & 49.09 & 12.71 \\
Urea & 96.12 & - & 264.00 & - & - & - & - \\
Midden soil & 89.97 & - & 2.78 & - & - & - & - \\
\hline
\end{tabular}

${ }^{\dagger}$ Diet $\mathrm{A}, 3.0 \%$ urea+2.0\% midden soil treated rice straw (ensiled); Diet B, 3.0\% urea+3.0\% midden soil treated rice straw (ensiled); Diet C, 3.0\% urea $+4.0 \%$ midden soil treated straw (ensiled); Diet D, 3.0\% urea+ $5.0 \%$ midden soil treated straw (ensiled)

The CP digestibility of different diets were 57.44 , $61.63,63.45$ and $64.80 \%$ in groups A, B, C and D respectively (Table 2 ) and $\mathrm{CP}$ digestibility was significantly higher $(p<0.01)$ in group $D$ in comparison with group $A, B$ and $C$. Addition of $5.0 \%$ midden soil with urea solution may helped in hydrolyzing urea which resulted better digestibility by the animals of this groups. This positive result on $\mathrm{CP}$ digestibility support the facts that associative effects of small quantities of supplement such as minerals or proteins enhances rumen fermentation leading to increased intake and digestibility. Hossain (2010) also found higher digestibility of $\mathrm{CP}$ in group receiving $2.50 \%$ midden soil and $2.50 \%$ chick pea as a source of urease with urea solution. Dajayanegra and Doyle (1989) reported both urea treatment and urea supplementation increased intake, rate of digestion and digestibility of nutrients. Significantly higher $(p<0.01)$ CF digestibility was found in diet $D$ containing $3.0 \%$ urea $+5.0 \%$ midden soil treated straw $(68.29 \%)$ than those in diet C containing $3.0 \%$ urea $+4.0 \%$ midden soil treated straw $(66.11 \%)$, diet B containing $3.0 \%$ urea $+3.0 \%$ midden soil treated straw $(65.19 \%)$ and diet $A$ containing $3.0 \%$ urea $+2.0 \%$ midden soil treated straw $(64.02 \%)$. The reason for higher digestibility of diet $D$ is the positive impact of urease enzyme from midden soil in releasing higher amount of ammonia and therefore penetrating the cell wall and make them soften resulted easy access of rumen microbes for working on CF. Increase digestibility of CF with the addition of urease enzyme sources was also observed by Ahmed (2003) with that $4.0 \%$ urea + $4.0 \%$ soybean treated rice straw improved the co-efficient of digestibility of crude fibre. The apparent digestibility of EE and NFE in diet D of these nutrients is statistically significant $(p<0.01)$ than $\operatorname{diet} A, B$ and $C$.
Table 2. Apparent digestibility of different experimental diets

\begin{tabular}{lccccc}
\hline ND & \multicolumn{4}{c}{ Diets $^{\dagger}$} & Sig. \\
\cline { 2 - 5 }$(\%)$ & $\mathrm{A}$ & $\mathrm{B}$ & $\mathrm{C}$ & $\mathrm{D}$ & level \\
\hline DM & $62.47^{\mathrm{c}}$ & $65.16^{\mathrm{b}}$ & $66.46^{\mathrm{b}}$ & $68.73^{\mathrm{a}}$ & $* *$ \\
OM & $50.79^{\mathrm{d}}$ & $55.48^{\mathrm{c}}$ & $59.95^{\mathrm{b}}$ & $61.45^{\mathrm{a}}$ & $*$ \\
CP & $57.44^{\mathrm{c}}$ & $61.63^{\mathrm{b}}$ & $63.45^{\mathrm{ab}}$ & $64.80^{\mathrm{a}}$ & $* *$ \\
CF & $64.02^{\mathrm{b}}$ & $65.19^{\mathrm{b}}$ & $66.11^{\mathrm{ab}}$ & $68.29^{\mathrm{a}}$ & $* *$ \\
EE & $70.71^{\mathrm{b}}$ & $73.25^{\mathrm{ab}}$ & $74.01^{\mathrm{a}}$ & $75.00^{\mathrm{a}}$ & $* *$ \\
NFE & $46.01^{\mathrm{c}}$ & $48.38^{\mathrm{bc}}$ & $50.18^{\mathrm{ab}}$ & $50.70^{\mathrm{a}}$ & $* *$ \\
\hline
\end{tabular}

${ }^{\dagger}$ Diet $\mathrm{A}, 3.0 \%$ urea $+2.0 \%$ midden soil treated rice straw (ensiled); Diet B, 3.0\% urea $+3.0 \%$ midden soil treated rice straw (ensiled); Diet C, 3.0\% urea+ $4.0 \%$ midden soil treated straw (ensiled); Diet D, $3.0 \%$ urea $+5.0 \%$ midden soil treated straw (ensiled); means with different superscripts in the same row differ significantly; $*, \mathrm{p}<0.05 ; * *, \mathrm{p}<0.01$; ND, nutrient digestibility; DM, dry matter; OM, organic matter; $C P$, crude protein; $C F$, crude fibre; $\mathrm{EE}$, ether extract; NFE, nitrogen free extract

\section{Digestible nutrients and nutritive value}

The average value of the digestible nutrients of OM, CP, CF, EE, NFE and TDN are shown in Table 3. The DCP contents of the different diets were $6.41,6.95,7.26$ and 7.47 for diet $A(3.0 \%$ urea + $2.0 \%$ midden soil treated rice straw), diet B (3.0 $\%$ urea $+3.0 \%$ midden soil treated rice straw), diet C $(3.0 \%$ urea $+4.0 \%$ midden soil treated rice straw) and diet D $(3.0 \%$ urea $+5.0 \%$ midden soil treated rice straw) respectively.

The variation in DCP content among the treatment groups were highly significant $(P<0.01)$. The results also indicated that DCP content increased with added urease source such as midden soil with urea treated straw based diet. This findings correspond well with the results of Hossain (2010) who reported that addition of plant urease source 
such as midden soil and pea seed meal with urea increased DCP content of rice straw. Malek et al. (2008) who observed that addition of soybean meal with urea significantly improved $(P<0.01)$ the DCP value.

Table 3. Nutritive values of different diets

\begin{tabular}{lccccc}
\hline ND & \multicolumn{4}{c}{ Diets $^{\dagger}$} & $\begin{array}{c}\text { Sig. } \\
\text { (\%) }\end{array}$ \\
\cline { 2 - 5 } & $\mathrm{A}$ & $\mathrm{B}$ & $\mathrm{C}$ & $\mathrm{D}$ & level \\
\hline DCP & $6.41^{\mathrm{b}}$ & $6.95^{\mathrm{b}}$ & $7.26^{\mathrm{a}}$ & $7.47^{\mathrm{a}}$ & $* *$ \\
DFC & $15.89^{\mathrm{b}}$ & $15.94^{\mathrm{ab}}$ & $16.12^{\mathrm{b}}$ & $16.47^{\mathrm{a}}$ & $* *$ \\
DEE & 5.45 & 5.65 & 5.73 & 5.83 & NS \\
DNFE & $19.83^{\mathrm{c}}$ & $20.99^{\mathrm{bc}}$ & $21.74^{\mathrm{ab}}$ & $23.05^{\mathrm{a}}$ & $* *$ \\
DOM & $47.59^{\mathrm{c}}$ & $49.55^{\mathrm{b}}$ & $50.86^{\mathrm{b}}$ & $52.82^{\mathrm{a}}$ & $* *$ \\
TDN & $54.40^{\mathrm{c}}$ & $56.62^{\mathrm{bc}}$ & $58.02^{\mathrm{ab}}$ & $60.11^{\mathrm{a}}$ & $* *$ \\
\hline
\end{tabular}

${ }^{\dagger}$ Diet $\mathrm{A}, 3.0 \%$ urea $+2.0 \%$ midden soil treated rice straw (ensiled); Diet B, 3.0\% urea $+3.0 \%$ midden soil treated rice straw (ensiled); Diet C, $3.0 \%$ urea $+4.0 \%$ midden soil treated straw (ensiled); Diet $D$, $3.0 \%$ urea $+5.0 \%$ midden soil treated straw (ensiled); means with different superscripts in the same row differ significantly $(p<0.01)$; ND, nutrient digestibility; DCP, digestible crude protein; DCF, digestible crude fibre; DEE, digestible ether extract; DNFE, digestible nitrogen free extract; DOM, digestible organic matter; TDN, total digestible nutrient

Rajeev et al. (1996) also found higher DCP value when straw was treated with soybean meal. Addition of $4.0 \%$ midden soil and $5.0 \%$ midden soil as a source of urease enzyme to urea treated straw at the time of treatment helped in increment of digestible crude fibre (DCF) value of group D (16.47\%) and group C (16.12\%) and the difference was statistically significant $(p<0.01)$. The DOM of groups A, B, C and D were 47.59, $49.55,50.86$ and $52.82 \%$ respectively and the differences were highly significant $(P<0.01)$. Addition of small amount of soybean meal to the urea solution as a source of urease increased digestibility of organic matter (Wanapat, 1985). There was no significant $(p>0.05)$ difference among the diets for DEE. Digestible Nitrogen Free Extract (DNFE) of diets for group A, B, C and D were $19.83,20.99,21.74$ and $23.05 \%$ respectively. DNFE of group D was statistically significant $(p<0.01)$ compared with the diets of group A, B and $C$. Values for TDN have been presented in Table 3 where it is evident that total digestible nutrient (TDN) of group D $(3.0 \%$ urea $+5.0 \%$ midden soil treated rice straw) was significantly higher $(p<0.01)$ than group $C(3.0 \%$ urea $+4.0 \%$ midden soil treated rice straw), group B $(3.0 \%$ urea $+3.0 \%$ midden soil treated rice straw) and group A $(3.0 \%$ urea $+2.0 \%$ midden soil treated rice straw). To produce a more rapid improvement in the nutritive value of straw, an exogenous source of urease is necessary in orders to hydrolysis the urea (Khan et al. 1999). Ahmed et al. (2003) also reported a higher $(p<0.05)$ TDN value in group fed on urea and soybean meal treated straw than only urea treated straw.

\section{Conclusion}

Nutritive value of rice straw in terms of nutrient composition, digestibility and TDN value improved significantly through treatment of rice straw with urea in addition with midden soil as urease sources. The addition of urease (midden soil) offered more flexibility in hydrolyzing urea in shortest possible time. For better utilization, rice straw can be treated with $3.0 \%$ urea $+5.0 \%$ midden soil.

\section{References}

Ahmed S, Khan MJ, Shahjalal M, Islam KMS (2003). Effects of feeding urea and soybean meal-treated rice straw on digestibility of feed nutrients and growth performance of bull calves. AsianAustralasian J ournal of Animal Science, 15: 522-527.

AOAC (2004). Official methods of analysis. ( $17^{\text {th }}$ edition). AOAC Internation Gaithersbury, Maryland, 20877-2417 USA.

Bae DH, Jung KK, Choi CB (1988). Studies on urea utilization as a source of ammonia for the rice straw treatment. Korean J ournal of Animal Science, 30: 282-283.

Dajayanegra A, Doyle PT (1989). Urea supplementation compared with pre-treatment. Effects on intake, digestion and live-weight change by sheep fed a rice straw. Animal Feed Science and Technology, 27: 17-30.

Goto M (1995). Ammoniation of barely straw effect on anatomical and physiochemical characteristics of the cell walls. Annales de Zootechnie, P. 44, 70.

Hossain MM (2010). Treatment of rice straw with urea and urease enzyme sources and its effect on nutrient digestibility and growth of local bull calves. MSc Thesis, Department of Animal Nutrition, Bangladesh Agricultural University, Mymensingh.

Jayasuriya MC, Perera HGD (1982). Ureaammonia treatment of rice straw to improve its nutritive value for ruminants. Agric. Wastes, 4: 143-150. 
Jayasuriya MCN, Pearce GR (1983). The effect of urease enzyme on treatment time and the nutritive value of straw treated with ammonia as urea. Animal Feed Science and Technology, 6: 123-131.

Kamruzaman M (2005). Effect of feeding urea supplemented and urea ensilied rice straw with or without soybean meal on growth and carcass characteristics of indigenous growing bull calves. MSc Thesis, Department of Animal Nutrition, Bangladesh Agricultural University, Mymensingh.

Khan MJ, Scaife JR, Hovell FD (1999). The effect of different sources of urease enzyme on the nutritive value of wheat straw treated with urea as a source of ammonia. AsianAustral Journal of Animal Science, 12: 1063-1069.

Kiangi EMI, kategile JA, Sundstol F (1981). Different sources of ammonia for improving the nutritive value of low quality of roughages. Animal Feed Science and Technology, 6: 377-386.

Malek MA, Khan MJ, I slam KMS (2008). Nutritive value of rice straw as affected by ensiling with urea and urease sources at various moisture levels. Indian Journal of Animal Science, 78: 182-185.

Munoze F, Joy F, Alibes X (1991). Treatment of leguminous residues with urea. Influence of dosage, moisture, temperature and addition of urease. Ann. Zootech, 40: 215-
225.

Rajeev PH, Tobioka H, Yasaki I, Pradhan R (1996). The effect of urea and ammonia treatments of rice straw on the voluntary intake digestibility and nitrogen retention of rice straw supplemented with soybean meal and fishmeal in goats. Animal Science and Technology, 67: 702-712.

Rangnekar DV (2005). Change in paradigm of animal nutrition research needed to benefit resource poor livestock producers. Proceedings of 12th Animal Nutrition Conference at Anand Agricultural University, Anand, Gujarat.

Saadullah M, Haque M, Dolberg F (1981). Effectiveness of ammoniation through in improving the feeding value of rice straw in ruminants. Tropical Animal Production, 6: 30-36.

Wanapat M (1985). I mproving rice straw quality as ruminant feed by urea treatment in Thailand. In Wanapat $M$ and Devendra C (Eds.). Relevance of Crop Residues as Animal Feeds in Developing Countries. Funny Press, Bangkok, Thailand. P. 121145.

Wanapat M, Sundstol F, Garma TH (1984). A comparison of alkali treatment methods to improve the nutritive values of straw. Animal Feed Science and Technology, 12: 295-309. 